\section{Response of Little-leaf Linden and Honey Locust to Rates of Organic and Mineral Nitrogen}

\author{
Calvin Chong \\ Horticultural Research Institute of Ontario, Department of Plant Agriculture, \\ University of Guelph, Vineland Station, ON LOR 2E0, Canada
}

Additional index words. nursery crops, nutrition, organic by-products, feather meal, Gleditsia triacanthos, Tilia cordata

Natural organic fertilizers have benefited agriculture since ancient times. These fertilizers, primarily processed wastes from the agrifood industry, are used today for producing organically grown food crops (Gagnon and Berrouard, 1994) and also as specialty fertilizers for lawns and home gardens (Tisdale and Nelson, 1975). Such uses offer alternative ways to dispose of organic waste by-products and conserve landfill space (Williams and Nelson, 1992).

While products such as bone meal, blood meal, and feather meal have been considered as sources of $\mathrm{N}$ for greenhouse (Choi and Nelson, 1996) and turf (Peacock and Daniel, 1992) use, a comprehensive literature search indicated no such consideration in modern ornamental nursery tree production practices. The objective of this study was to evaluate and compare how two shade tree species responded to various rates of $\mathrm{N}$ from an organic and a mineral source.

In mid-May 1992, 2-year-old budded whips of honey locust (Gleditsia triacanthos var. inermis Willd. 'Skyline') and of little-leaf linden (Tilia cordata Mill. 'Glenleven') were planted in a split-plot design with species as main plots (four replications). The soil was a Toledo fine sandy loam, with $\mathrm{pH}$ of 6.5 and adequate levels of $\mathrm{P}\left(28 \mathrm{mg} \cdot \mathrm{kg}^{-1}\right)$ and $\mathrm{K}(212$ $\mathrm{mg} \cdot \mathrm{kg}^{-1}$ ) (Ontario Ministry of Agriculture, Food and Rural Affairs, 1994).

There were seven subplot treatments: 0 , 50,100 , or $200 \mathrm{~kg} \cdot \mathrm{ha}^{-1} \mathrm{~N}$ of both granular $\mathrm{NH}_{4} \mathrm{NO}_{3}(33-0-0)$ and granulated feather meal (13-0-0) (Terra Care International Corp., Elmira, Ont.). Each subplot unit consisted of six trees of each species. Spacing was $5.0 \mathrm{~m}$ between and $1.8 \mathrm{~m}$ within rows. Guard trees were planted between subplots and at the ends of each row. From 1992 to 1995, each Ntreatment was broadcast over the entire subplot, two-thirds in April and one-third in early October.

After planting, whips were pruned to uniform height $(1.8-1.9 \mathrm{~m})$. Each winter, trees were pruned lightly to remove structurally weak branches, to maintain form, and/or to

Received for publication 26 Jan. 1999. Accepted for publication 26 May 1999. The technical assistance of Bob Hamersma is acknowledged.The cost of publishing this paper was defrayed in part by the payment of page charges. Under postal regulations, this paper therefore must be hereby marked advertisement solely to indicate this fact. Graphically, the model represents two lines, provide a branch-free trunk up to $1.5 \mathrm{~m}$ from the ground. Plots were cultivated every 4-6 weeks. Each August, leaf samples were analyzed for total N, P, K, Ca, Mg, Fe, Mn, and Zn. Each October, height and trunk diameter $(5 \mathrm{~cm}$ above the graft union) of each tree were measured.

Data were analyzed by regression (Chong and Cline, 1994). Each response was regressed within species on level of organic or mineral $\mathrm{N}$. one for each $\mathrm{N}$ source radiating from a common intercept. When the two regressions did not differ at $P \leq 0.05$, a common regression was fitted. The coefficient of determination for each set of responses was expressed in terms of "partial $r^{2 "}\left(p r^{2}\right)$, which measured the strength of the response relationship after removing replication effects (Chong and Cline, 1994).

Trees of both species grew vigorously throughout the 4 years in this relatively fertile soil. After the fourth season, trunk diameters of honey locust trees were proportional to the quantity of $\mathrm{N}$ applied, responding similarly to the organic $(\mathrm{O})$ and mineral $(\mathrm{M})$ sources $(\mathrm{com}$ bined regression, $\mathrm{Y}_{\mathrm{om}}=61+0.015 \mathrm{X}, p r^{2}=$ 0.79 , Fig. 1). Height $(3.8 \pm 0.3 \mathrm{~m})$ was unaffected. Growth of little-leaf linden was not affected by any $\mathrm{N}$ treatment (trunk diameter, $72 \pm 0.6 \mathrm{~mm}$; height, $3.7 \pm 0.3 \mathrm{~m}$ ).

Data for earlier years (not shown) indicated that the effect of $\mathrm{N}$ rates on trunk diameter of honey locust began to be statistically significant after the second season. After the third season, most trees of both species were of marketable size (50-mm trunk diameter). Annual analysis indicated adequate quantities of all foliar nutrients in both species from all

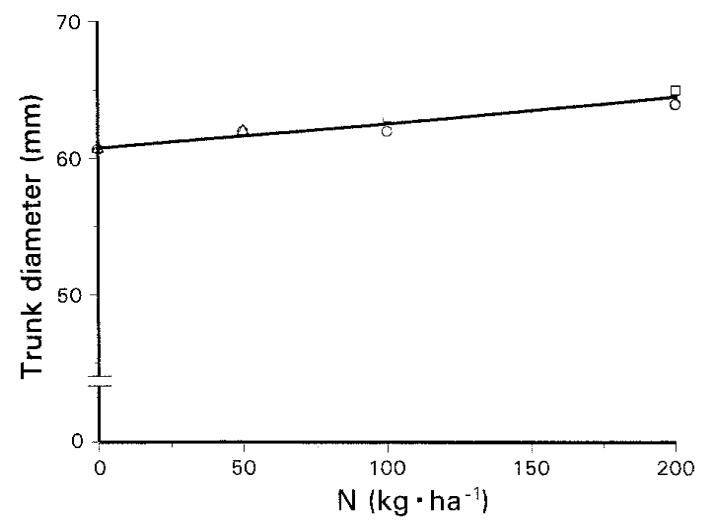

Fig. 1. Response of honey locust to level and source of $\mathrm{N}$ after the fourth growing season. Organic $(\mathrm{O})=$ circles; mineral $(\mathrm{M})=$ squares; common curve, $\mathrm{Y}_{\mathrm{om}}=61+0.015 \mathrm{X}, \mathrm{pr}^{2}=0.79$. 